\title{
FOREIGN POLICY CHANGE IN A POLARIZED TWO-PARTY SYSTEM: GREECE AND TURKEY'S EU CANDIDACY
}

\author{
Article published in Southeast European and Black Sea Studies 15(1): 19-36, 2015 \\ http://www.tandfonline.com/doi/full/10.1080/14683857.2014.1002293
}

\author{
Angelos-Stylianos Chryssogelos \\ angelos.chryssogelos@kcl.ac.uk
}

\begin{abstract}
This article aims to theorise about how dynamics of party competition influence government decisions to engage in foreign policy change. It shows how a focus on the functioning of polarized two-party competition in Greece in the late 1990s sheds light on crucial questions concerning the content, timing and institutionalization of Greece's decision to allow the EU to grant Turkey candidate-member status. The article problematizes this foreign policy change as a decision influenced, among other factors, by the demands of party competition, and especially the strategy of the then ruling socialist party. More generally, this article shows how a focus on party politics complements in various interesting ways our understanding of foreign policy decisions and foreign policy change. Party system dynamics are shown to act as significant intervening factors between determinants of foreign policy usually analyzed in the literature and eventual foreign policy change.
\end{abstract}

Keywords: foreign policy, foreign policy change, political parties, Greek-Turkish relations, party systems, polarization, PASOK, Greek foreign policy, Helsinki 


\section{INTRODUCTION}

The decision of Greece to allow the EU to grant Turkey candidate-member status in the December 1999 EU Council in Helsinki marks the most important change in Greek foreign policy since the establishment of the democratic regime in 1974. In this article I aim to draw attention to a little-discussed dimension of the process that led to Greece's foreign policy change, namely the dynamics of the Greek party system that embedded the strategies of foreign policy decision makers and informed to a significant degree the timing and content of that change. Party politics is a relatively understudied topic in the analysis of foreign policy, however in democratic regimes party competition filters in a substantial way the effect of factors usually analyzed in works of foreign policy analysis. Especially in Greece, where political parties have occupied a 'hegemonic position' in society (Kalyvas 1997, 99), the absence of a systematic incorporation of findings from the party politics literature in the study of foreign policy is all the more striking.

This article has a double goal: The first is to show how a focus on the dynamics of party competition significantly complements our understanding of foreign policy change, and especially of such aspects as the content of new policies, the timing that change takes place, and the degree of institutionalization of new policies. The second is to show how, in Greece, the key systemic characteristic of party competition between 1981 and 2011 polarization in a two-party system - filtered the ways Greece responded to outside challenges, new policy ideas came to influence policymaking, and new foreign policies became institutionalized in the long term. The article proceeds as follows: The first section presents the topic at hand (change in Greek foreign policy in the late 1990s) and discusses some prominent explanations of it. The second section presents the main structural characteristics of party competition in Greece, and the effects of a polarized two-party system on the outputs and contestation of foreign policy since 1981. The third section contains a theoretical discussion of how features of party competition, and especially polarization in a two-party system, are expected to influence three aspects of foreign policy change: its timing, content, and institutionalization. The fourth section contains the empirical bulk of the argument, showing how a party politics perspective complements existing accounts of Greek foreign policy change in Helsinki. The fifth section will conclude.

\section{GREEK FOREIGN POLICY CHANGE: FACTS AND CONCEPTUAL APPROACHES}

After the Turkish invasion of Cyprus in 1974, Greek-Turkish relations became strained by an increasing number of Turkish demands concerning sovereignty over air and sea in the Aegean (Heraclides 2007; Valinakis 1989) ${ }^{1}$. Added to the Cyprus impasse, this palette of 'open' bilateral issues created a Cold War-like atmosphere between two NATO allies 
that led three times (1976, 1987 and 1996) to the brink of war. The tone in Greek-Turkish relations changed significantly after 1996 and the rise to power of Prime Minister Costas Simitis of the Panhellenic Socialist Movement (PASOK) who sought to decrease tensions and embed bilateral relations in a European framework. His strategy culminated in the 1999 EU Council in Helsinki, where Greece threatened to veto the EU enlargement if Cyprus were not accepted in the EU without preconditions on the resolution of the occupation problem. In return, Greece allowed the EU to grant Turkey candidate-member status and adhered to a timeline for resolution of outstanding problems in the Aegean by 2004 through negotiation and, if this failed, recourse to the International Court of Justice (ICJ) (Heraclides 2007, 195-196; Tsakonas 2010, 91-95). Greece accepted the validity of Turkish demands in the Aegean (Tsakonas 2010, 19), but hoped that a 'Europeanized' Turkey would be a more amenable partner in negotiation.

At the time, the main opposition party, New Democracy (ND) under Costas Karamanlis, opposed the Helsinki decision (Heraclides 2007, 198). Helsinki was de facto endorsed by the Greek public in the elections of April 2000, which PASOK won with a razor-thin margin against ND. Thereafter, the Simitis government initiated negotiations on outstanding issues in the Aegean and supported a reunification plan for Cyprus. A comprehensive deal between Greece and Turkey scheduled for 2004 was derailed by electoral developments. In March 2004, PASOK lost the election to ND and Karamanlis became Prime Minister, suspended bilateral negotiations and offered lackluster support to the reunification plan in Cyprus. That plan was resoundingly rejected by Greek-Cypriots in a referendum in April 2004. In May 2004 Cyprus was admitted to the EU. In December 2004 the Karamanlis government forewent the possibility to refer outstanding bilateral issues with Turkey to the ICJ. Instead, it decided to use Turkey's accession process to both deepen relations and extract concessions down the way (Heraclides 2007, 204-206). Since then, successive Greek governments have tried to maintain a calm climate in bilateral relations and support Turkey's European course, even if changes in Turkey and the Euro crisis have left little room for active initiatives.

Early academic analyses of Simitis' foreign policy stressed the inherent strength of Europeanization in providing policy solutions and prescribing a vision of a liberal international order within which reconceptualized Greek national interests would be served (Ioakimidis 2000; Keridis 2001). A more sanguine account can be found in Tsardanidis and Stavridis (2005), who see Europe as an arena where Greece can promote effectively its goals rather than as a source for change of Greek policy ${ }^{2}$. International relations literature pointed to the fact that Greek foreign policy change was a response to wider changes in the region after the end of the Cold War (Ifantis 2004). Among more recent analyses, the most empirically exhaustive is that of Tsakonas (2010). Tsakonas lays a big premium on the personality of Simitis and his ability to find solutions in the face of policy failure. To Simitis' 'agentic' culture he contrasts the 'underdog' culture of the Greek state and society. In this view, Greek foreign policy was Europeanized through the agency of 
Simitis, precisely because Europe represented the type of problem-solving and modernizing culture Simitis wanted to transfuse into Greece. Blavoukos and Bourantonis (2012) on the other hand see foreign policy change as an outcome of political entrepreneurship (whereby political actors implement new policy ideas in order to reap future political rewards) under permissive institutional conditions. Blavoukos and Bourantonis locate the initiative for policy change in the preferences of entrepreneurs like Simitis, while they ascribe crucial role to the centralized system of government in Greece that allows leaders to implement changes almost unhindered once in power.

Useful as these works are, they leave some theoretical and empirical questions unanswered. Existing literature on Greek foreign policy, for example, is quite ambiguous as to what kind of change Helsinki actually was. Did it represent a change of tactics towards the pursuit of the same goals, or did it entail a rearticulation of foreign policy goals as such? Following Charles Hermann's (1990) typology and analysis of four gradations of foreign policy change (change of means, tactics, strategy/goals and of interests/strategic orientation altogether), it is probably most accurate to say that Helsinki is located somewhere between a change of means and a redefinition of a foreign policy goal as such. As we will see, the Greek government at the time argued in both directions. But this ambiguity of the exact nature of change in Helsinki is not something the literature tries to explain, but instead reflects back on scholarly work itself. Put simply, the way a scholar conceptualizes the change in Helsinki influences which theoretical framework she uses to explain it $^{3}$. If one focuses on Helsinki's novel aspects, one is predisposed to look at the effects of European norms and the strength of new policy ideas ${ }^{4}$. If one emphasizes continuity in Greek foreign policy after Helsinki, one also tends to ascribe primary importance to the strength of traditional conceptions of Greek interests or the adaptation to changing international conditions that required recalibration of means and ends of Greek foreign policy. Analyses of both streams shy from explaining the content of change itself - especially how the specific balance between continuity and change in Greek foreign policy arose. Here I am conscious of the need to locate Helsinki in a broader conceptual framework of foreign policy change and to problematize the kind of change that Helsinki eventually became. For this reason, I intend to leave the foreign policy factors I am interested in (party politics) to highlight for themselves how a specific policy response arose and how it came to be located in the place that it did in the continuum of foreign policy change developed by Hermann.

The timing of change is also vaguely accounted for by prominent analyses. Leadership and agency fail to explain why Simitis (who was acknowledged to be a very little charismatic leader) would be the one to succeed in promoting foreign policy change, especially given how significant a departure it represented from his own party's earlier positions. Blavoukos and Bourantonis complement their framework with the qualifying condition of a security crisis that paves the way for change - in the case of Simitis, the Imia crisis of 1996. The Imia crisis was unquestionably a shock, but by itself it cannot explain foreign policy change. Taken together, Imia and Simitis' agency may account for why 
change took place when it did, but not for why it did not take place earlier - for example under Konstantinos Mitsotakis, ND leader and Prime Minister in 1990-1993, himself an exponent of the 'agentic culture' per Tsakonas, who wanted to anchor Greece to Europe and adapt its foreign policy to the demands of EU membership ${ }^{5}$. If Helsinki was a response to macro-level pressures on Greek foreign policy after the Cold War or to the direct challenges posed by the Imia crisis, none of the existing accounts explains why very few tangible changes took place before December 1999. Blavoukos and Bourantonis engage with the question of the time lag, but are forced to take recourse to factors beyond their explanatory model and mention party-political conditions that kept Simitis from instituting his preferred policy earlier. The partisan dimension is also present in Tsakonas and Heraclides' analyses. Clearly the role of party politics needs to be systematically incorporated in analyses of this foreign policy change.

Finally, one issue that existing analyses overlook is institutionalization of the new foreign policy. Regardless of whether one sees the change in Helsinki as a rational response to changing international conditions or as the result of socialization and the impact of Europe, the fact that it only required a government change in 2004 for crucial elements of the Helsinki decision to change raises the theoretical need to clarify which conditions affect the degree of institutionalization of a new foreign policy.

\section{THE GREEK PARTY SYSTEM AND FOREIGN POLICY 1974-1999}

For 30 years Greek party politics revolved around competition between two major parties, the conservative New Democracy (ND) and the socialist Panhellenic Socialist Movement (PASOK). That two-party system was instituted with PASOK's victory in 1981 and its dynamics were an object of debate among scholars of Greek politics. Mavrogordatos (1984) took into account the role of a then strong Communist party to the left of PASOK and the division of Greek politics in three camps - Right, Centre and Left - and characterized the Greek party system as one of 'limited but polarized pluralism'. Later, Pappas, focusing on the parties with credible chance of gaining power, claimed that the Greek party system had become a typical two-party system (Pappas 2001, 2003) where the two parties were increasingly seeking the middle ground. This was in accordance with developments throughout the 1990s, when PASOK and ND converged to a policy profile of economic liberalization and modernization. Yet policy convergence contrasted with the fact that each party, when in opposition, viciously undermined the government. Following the Eurozone crisis and the collapse of both parties' support, Pappas argued that bipolar competition between ND and PASOK had in fact been a polarized one (in a strategic rather than ideological sense) (Pappas 2013).

The Greek two-party system was peculiar not just because each of the two parties defined itself as opposition to the other (a normal feature of two-party systems), but because that competition was animated by the effort to discredit the opponent more than 
attract middle-ground moderate voters ${ }^{6}$. This polarized two-partyism is even more peculiar given the small policy differences between the two parties, especially in the 1990s and 2000 s, which makes the use of the term 'polarization' (that is very common in Greek political parlance) problematic from an analytical and comparative perspective. In fact, two-party competition in Greece resembled competition between two programmatically rigid and incompatible parties, when this was patently not the case, at least after the 1980s. In the place of policy differences, polarization in the Greek party system can be explained from a systemic perspective with reference to the origins of the two-party system in the three-camp structure of Greek politics (as per Mavrogordatos), and in terms of (absence of) policy content with reference to the historical identities carried over from civil conflicts of the $20^{\text {th }}$ century and the fierce competition for clientelist spoils (Kalyvas 1997). These factors explain the fact that two-party competition in Greece was polarized as if it were programmatic - a policy-empty polarization as it were. Yet, what was the exact content and language of polarization that animated two-party competition?

The most refined analysis of the mechanics of polarization in Greece has been offered by Moschonas (1994), who explained how the party-heir of the Centre political identity, PASOK, had built its political dominance after 1981 on an assiduous anti-Right polarization and the discursive construction of a majoritarian 'democratic camp' (spanning the Centre and Left political identities) (also Kalyvas 1997, 86-87). By emphasizing its own character as a bulwark against the heir of the political identity of the Right, ND, from returning to power, PASOK (and especially its charismatic founder, Andreas Papandreou) created a partisan identity that merged the traditional opposition of the Centre camp to the Right with the frustrations of the Left as the loser of the Civil War. Moschonas argued that, as the anti-Right camp was bigger than the Right, PASOK's ability to energize the antiRight feelings of voters of this camp also ensured its dominance. Presenting its competition with ND in binary apocalyptic terms was a self-reinforcing strategy for PASOK ${ }^{7}$. On the other hand, ND, confined to the political identity of the Right, had to engage with polarization in a different way: While it had to energize its own supporters with constant opposition to PASOK's actions in government, it also had to develop a profile that appealed to voters of the non-Right camp (Pappas and Dinas 2006).

In all, PASOK ruled for 21 years between 1981 and 2011 (1981-1989, 1993-2004 and 2009-2011), and ND 8 (1990-1993 and 2004-2009). The contestation and outputs of foreign policy during this period closely reflected the dynamics of polarized two-party competition. PASOK's foreign policy in the 1980s represented a significant departure from the pro-Western foreign policy of Greece of the previous half century. While ND had severed relations with NATO after 1974, it had put forth Greece's entry to the European Economic Community as an alternative anchoring point to the West. PASOK had been vehemently opposed to entry to the EEC but after it came to power it did not try to take Greece out of NATO or EEC. Instead Papandreou put forth a maverick foreign policy in the context of the Cold War, a rapprochement with the 'Third World' and Arab states, and, 
most importantly, a policy of tension against Turkey (Huliaras 1989; Loulis 1984). Even though ND governments of 1974-1981 had tried to keep open the channels of communication with Turkey, PASOK suspended all but most basic contacts.

After 1981, ND supported a policy of moderation towards Turkey (Tsakonas 2010, 48). However PASOK's dominance in 1981-1989 institutionalized a new foreign policy whereby Greece only accepted as an issue the demarcation of the continental shelf in the Aegean, which should be resolved in the ICJ, and declined to discuss any other issues concerning air space and sea borders (Athanassopoulou 1997, 77; Heraclides 2007; Tsakonas 2010, 46-47) ${ }^{8}$. Greece used the EEC as a forum to voice its concerns over its disputes with Turkey in Cyprus and the Aegean. This added to the perception that Greece was a 'difficult' partner in the EU, leading to its isolation on various occasions (Tsakonas 2010, 48-51; Tsoukalis 2000, 47). Consistent with its effort to overcome polarization, ND internalized the continental shelf policy, even though it continued to fret that PASOK would marginalize Greece within the West and Europe.

After the end of the Cold War, a different foreign policy issue, the Macedonia-name dispute, came to upset the balance of the Greek party system. The mass mobilization for the name of Macedonia crystalized a latent cleavage running through the old structure of Right, Centre and Left, and highlighted the increasingly tenuous hold of polarization over Greek voters in the post-Cold War world (Vernardakis 2011, 165). This cleavage pitted those holding fundamental views of Greek national interests against modernizers who promoted watered-down understandings of Greek national interests for the sake of Greece's connection with Europe and domestic modernization (Nicolacopoulos 2005, 272; Tsoukalis 2000, 41). This cleavage ran through the party system, as evidenced in the split between conservatives and liberals in ND that brought down the Mitsotakis government in 1993, and the succession race in PASOK between modernizers and populists after Papandreou stepped down in 1996 (Vernardakis 2011, 241-242).

The dynamics of two-party polarization were still present in the 1990s: PASOK challenged ND's efforts in 1990-1993 to embed Greek foreign policy issues (GreekTurkish relations and the Macedonia-name issue) in a European framework and promote more 'pragmatic' readings of the Greek national interest. After the 1996 change of leadership in PASOK and the entry into the post of Prime Minister of modernizer Costas Simitis, modernizing pro-European foreign policy ideas were now being carried by the leadership of a political party whose dominance had been until then based on a much different policy set. ND on the other hand, disarrayed after two consecutive defeats in the elections of 1993 and 1996, was faced with the opposite dilemma: To face a governing

party that was increasingly moving towards its own positions, thus increasing its own marginalization.

\section{TWO-PARTY SYSTEMS, POLARIZATION AND FOREIGN POLICY CHANGE}


Even though it feels like an obvious topic of research in foreign policy analysis, there has been relatively little conceptual and comparative work on foreign policy change as such $^{9}$. What seems to arise from these works is a conceptualization of foreign policy change primarily as a response to changes in a state's international environment. In systemic views of international relations, the degree to which foreign policy will change reflects the nature of international pressures on a state's foreign policy. In practice it is more accurate to say that these international pressures will be 'read' differently by policymakers, political actors, and parties. Foreign policy change has to be problematized as a specific type of response that arises out of a certain bundle of decision-making processes and domestic political conditions. It is neither automatic nor inevitable but a contingent policy decision in face of new international conditions. And while new policy ideas may arise in the minds of policymakers or in various institutional environments, how they are put into practice depends on the general context of policymaking.

In liberal democracies foreign policy decisions are influenced, among others, by features of party competition, as they intervene between specific policy responses to external change and the final implementation of a new foreign policy ${ }^{10}$. Party system scholars see political parties as embedded in structures of competition that are characterized by their format (number of relevant parties) and properties (patterns of interaction between parties) (Bardi and Mair 2008; Sartori 1976). Party systems codify parameters of competition (patterns of opposition and interaction) and a 'language of politics' that gives meaning to interaction among parties. This language of politics does not just underline competition between parties, but also structures the electorate to the confines of competition between established forces and anticipates the rise of challengers (Mair 1997). Politicians in party democracies are constituted by their party systems in the sense that they are provided with conceptions of political identity (who is against whom and for what reason) and understandings of tactical interest ${ }^{11}$. The way a party's foreign policy positions will be translated into state foreign policies is not simply a matter of direct implementation of partisan preferences when the party is in power, but the outcome of interactions within the party system. Thus the party system becomes an intervening variable between changing international conditions, new policy ideas, and eventual foreign policy change. One can hypothesize then that features of a party system (along with other factors of course) will influence the way political parties contest foreign policy, and therefore condition the ways new policy ideas (responses to new international conditions) become translated into new policies.

In a 'majoritarian' democracy (with executive dominance over the parliament and single-party governments) (Lijphart 1999), it is normal to expect each major party to define itself to a large degree as opposition to what the opponent is doing. The peculiarity of the Greek party system was that programmatic convergence went hand in hand with a persistent structure and language of polarization, within which new policy ideas had to be 
articulated and put through. Polarization as a systemic feature superseded policy convergence, thus making Greek two-partyism not just a competition between parties that oppose each other as a matter of principle (which is normal in two-party systems, even when the two parties are indistinguishable policy-wise, e.g. in Ireland (Mair 1987)), but a competition akin to the one between deeply ideological and programmatic parties that see each other as fundamentally incompatible and even dangerous (e.g. Great Britain in the early 1980s (Rose 1984)). In foreign policy, the elites of both PASOK and ND had by the late-1990s converged to the acceptance of the need for Greece to remain anchored in Europe and hence also, in light of the post-Cold War strategic environment, to change aspects of its foreign policy as they had been institutionalized since the 1980s. However, pushing through and contesting new policies could only take place in a framework not only of simple government-opposition dynamics, but of a specific language of delegitimating the opponent. This discursive framework of polarization within which two-party system dynamics were embedded had important repercussions on specific aspects of foreign policy change.

In majoritarian systems with policy-based polarized two-party competition, one expects foreign policy change to take place in a way that reflects developments in political competition (e.g. party turnover in government), even in the absence of international stimuli for change. Party turnover in government when polarization in Greece still reflected incompatible programmatic agendas (when PASOK first entered power in 1981 and ND returned to power in 1990) ${ }^{12}$ produced significant shifts in foreign policy, and foreign policy was part of intense contestation between the two parties during that time. The two parties did not just bitterly contest tactics of foreign policy, but polarized two-party competition also produced new long-lasting understandings of Greek interests (the continental shelf position is the most obvious and durable outcome of this period for Greek foreign policy, following PASOK's rise as a dominant political force in the 1980s). If programmatic distance between the two main parties is small on the other hand, chances are foreign policy change will not be endogenous to party competition (e.g. follow party turnover in power) but instead react to external stimuli (as expected by most theories of foreign policy change).

Generally a two-party system with single-party governments dominating policymaking is inviting for bearers of new policy ideas supporting change: If they can take over one of the two major parties, they can hope that their ideas will be implemented with little regard for opposition concerns. But the interaction between polarization and policy distance conditions how new policy ideas are expected to play out. In policy-based polarization (as Greece was in the 1980s) only ideas that reflect the programmatic and ideological incompatibility between the two parties can hope to take hold of either of them. On the other hand, two-party systems with high systemic polarization but small policy distance between the major parties, as Greece was in the 1990s, present a mix of constraints and opportunities for new policy ideas: Small policy distance means that each party is more 
open to new policy ideas than what it would be under conditions of ideologically polarized competition; and polarization further underpins the tendency of the party in government to put through foreign policy change over the concerns of the opposition. But polarization also serves to curtail the effect of these ideas, and the potential degree of change these imply, if these ideas are seen to contradict a party's strategy in polarization or overtly decrease policy distance between two parties that after all have to maintain the image of fundamental opposition between them.

This raises the question why such policy ideas that may seem incompatible with a party's self-understanding as fundamental opposition to another party would become accepted in the first place. To answer this question one needs to look closer to the specific content of party competition embedding a two-party system. I assume that in a polarized party system not all parties are constrained the same way by polarization. Polarization is a favourable condition for some parties, but an obstacle for others. As we saw, in Greece after 1981 the polarization of the party system was wholly congruent with the strategic needs of PASOK, which had imposed a specific reading of what party competition was about and thrived on it. In this context, new policy ideas are easier to put through when carried by parties that can match them with the dominant language of polarization, as opposed to being carried by parties that want to overcome this language. This answers to a considerable extent the question of timing of foreign policy change: Until new policy ideas take over a party occupying a favourable position in the overall structure of polarization, ideas for change may waver in search of a host or may be defeated if carried by parties hampered by the direction of competition. And the best way for new foreign policy ideas to take over a party in a favourable position of polarization is for their proponents to portray them as congruent with this party's strategy of polarization - which may call for these policy ideas to be toned down and their potential to bring about a high degree of foreign policy change to be curtailed.

Finally, polarization also affects the degree of institutionalization of a new foreign policy. New policies (especially in foreign policy) usually survive simple change of government. However, in programmatically polarized party systems, there is always the chance that elements of a new foreign policy will change with party turnover in government (even in the absence of external stimuli, if the two parties represent fundamentally antithetical models of domestic governance). As a rule of thumb, one can say that a new foreign policy becomes entrenched the more time it remains unaltered. The potential for reversal of foreign policy change also decreases as policy distance between parties decreases. However, institutionalization of a new foreign policy will still suffer under polarization, even if parties have converged programmatically. I expect that a new foreign policy will remain partially institutionalized under conditions of policy-empty polarization, as every time a party enters office it will want to showcase some principled opposition to its predecessor's policies, with the potential of reversal of this new foreign policy decreasing the more time passes from when it was enacted. 


\begin{tabular}{|c|c|c|c|c|}
\hline $\begin{array}{l}\text { Type of two- } \\
\text { party system }\end{array}$ & $\begin{array}{l}\text { Are external stimuli } \\
\text { necessary for } \\
\text { foreign policy } \\
\text { change? }\end{array}$ & Degree of change expected & Timing & $\begin{array}{c}\text { Institutiona- } \\
\text { lization of } \\
\text { new foreign } \\
\text { policy }\end{array}$ \\
\hline $\begin{array}{c}\text { Policy-based } \\
\text { polarization }\end{array}$ & $\begin{array}{c}\text { No } \\
\text { (change can follow } \\
\text { party turnover in } \\
\text { power) }\end{array}$ & $\begin{array}{c}\text { Potentially very high } \\
\text { (strategic goals or even wholesale } \\
\text { reorientation) }\end{array}$ & $\begin{array}{l}\text { Party turnover in } \\
\text { government }\end{array}$ & Precarious \\
\hline $\begin{array}{c}\text { Policy-empty } \\
\text { polarization }\end{array}$ & Yes & $\begin{array}{c}\text { Potentially high } \\
\text { (will reflect specific polarization } \\
\text { needs of host parties) }\end{array}$ & $\begin{array}{c}\text { Policy ideas } \\
\text { pushing for change } \\
\text { become hosted by a } \\
\text { party in a } \\
\text { favourable position } \\
\text { in polarization }\end{array}$ & Partial \\
\hline $\begin{array}{c}\text { No } \\
\text { polarization }\end{array}$ & Yes & $\begin{array}{l}\text { Will reflect the strength of } \\
\text { international stimuli, but normally } \\
\text { modest }\end{array}$ & $\begin{array}{l}\text { Policy ideas } \\
\text { pushing for change } \\
\text { become hosted by } \\
\text { either party }\end{array}$ & Secure \\
\hline
\end{tabular}

Table 1:

The effect of polarization in two-party systems on dimensions of foreign policy change

\section{GREEK FOREIGN POLICY CHANGE IN HELSINKI AND PARTY SYSTEM POLARIZATION}

In a system of policy-empty two-party polarization we expect that international conditions are the main source of foreign policy change. In the Greek foreign policy change in Helsinki, the international context in late 1999 was of course a decisive factor for the new foreign policy to unfold, as the EU was discussing its forthcoming enlargement and enough governments of member-states were open to the prospect of Turkey eventually becoming a member (or at least extending the candidate status at that point). However the Greek government found itself in the position to push for what became the Helsinki compromise only after a long period of resistance by the governing party. I argue that, even in light of conducive international factors, had this partisan hurdle not been cleared, the new foreign policy would not have been enacted on the time it did. What is more, the dynamics of two-party competition in Greece go a long way towards explaining not only the specific timing of the Helsinki change during the first term of the Simitis government, but why Europeanization of foreign policy arose and took hold ten years after the end of the Cold War.

Most analyses of the foreign policy change that culminated in Helsinki take into account party politics to explain why Simitis was unable to implement his foreign policy immediately after he came into power in 1996, despite the burden of the Imia crisis. Much like his economic policies of budgetary consolidation met with severe resistance by the party's populist left wing (Vernardakis 2011, 46), that same wing also set obstacles to his 
initiatives towards dialogue with Turkey (Athanassopoulou 1997, 96; Heraclides 2007, 165-178; Tsardanidis 1998, 308-309). Local and European elections defeats in 1998-1999 were a signal to the Simitis government that its program of austerity had reached the limits of tolerance among the party's traditional audience in the 'democratic camp' (Nicolacopoulos 2005, 277; Vernardakis 2011, 58-60). PASOK was trailing ND in opinion polls throughout 1998 and the first half of 1999, something ascribed to disillusion of the party's traditional voters with Simitis' policies. However, in the course of 1999, Simitis and his government managed to overcome intra-party opposition, which allowed his government to institute the change in Helsinki in December (Heraclides 2007, 65-78). That Simitis managed to win over his own party is generally seen as the decisive juncture for other factors (like new policy ideas or the normative attractiveness of Europe) to play out and Helsinki to take place (Heraclides 2007, 194; Tsakonas 2010, 75).

The most forceful justification for the change that became Helsinki was 'domestic' in nature (Economides 2005, 481-482; Kranidiotis 2000, 32). The prospect of entering the Eurozone remained very popular among a majority of Greeks (even if much fewer people were willing to shoulder the required sacrifices, Vernardakis 2011, 26-39). Even though that same public opinion (including many PASOK voters) was also very reluctant towards the idea of Turkey becoming an EU candidate-member ${ }^{13}$, the popularity of Europe allowed the government to match the idea of 'Europeanized' relations with Turkey to a domestic policy set that was quite popular. Greece needed normalization of its relationship with Turkey both because fiscal consolidation called for decrease of military spending (Couloumbis 2000, 382; Tsakonas 2010, 62-64), and because entering the 'hard core of Europe' required a recalibration of Greek foreign policy towards European interests and practices (Tsoukalis 2000, 49-50).

The new foreign policy (and Helsinki specifically) could be seen then as consistent with PASOK's electoral goals. Yet the party mechanism and its traditional voter base had shown little enthusiasm for Europeanization since 1996 - be it of domestic or foreign policies. Under conditions of binary polarization, Simitis would have to convince that the 'domestic' justifications of the new foreign policy were consistent with the party's interests in a structure of polarization (Tsakonas 2010,77). This indeed happened as a series of fortunate events fed success for the government: As the prospect of Greece 'locking in' its entry to Economic and Monetary Union (EMU) increased throughout the fall of 1999, and as the standing of the government improved in opinion polls ahead of elections that would have to be called no later than October $2000^{14}$, so did the willingness of members of all PASOK wings to hedge their bets on Simitis' agenda across both domestic and foreign policy (Vernardakis 2011, 26).

This became all the easier since PASOK was favourably placed in the structure of polarization. As the party had created and been identified with the dominant narrative of party competition in Greece (the democratic camp against the Right), the new foreign policy ideas that pointed towards change would have much better chances if carried by a 
party in a favourable position in the party system, provided that these foreign policy ideas could be assimilated in this narrative. In fact, this is exactly what happened: Once an inclusive message of reform of the Greek polity beyond partisan divisions, by 1999 modernization had become absorbed in the partisan strategy of apocalyptic struggle between PASOK and the Right. The normative terms of the conflict changed: the 'progress' of the 1990s was no longer the populist economic redistribution of the 1980s but European integration and social modernization. The 'reaction' of the 1990s was no longer a semi-authoritarian Right but a conservative, backward looking ND that would marginalize Greece in Europe ${ }^{15}$. The point when the PASOK mechanism was convinced of the congruence between modernization and anti-Right polarization (sometime during fall 1999) was the turning point after which the new foreign policy also became possible.

The conceptual lens of the party system does not just explain the timing of the foreign policy change within the context of Simits' rule; it can also explain why Europeanization of Greek foreign policy only took place in the late 1990s and only after having been accepted by a party that previously had been identified with populist foreign policy. A comparison between the position Simits and PASOK found themselves in in 1999 and the experience of the pro-European ND government under Mitsotakis in the early 1990s is instructive as regards the role of party politics in the timing of foreign policy change. The position of modernizing leaderships in both cases was precarious, and the danger of internal split of each party equally big. Yet the government of Mitsotakis was the one that suffered a split and defeat in 1993, while Simitis not only survived but won reelection in 2000. Even if it was significantly pro-Western, Mitsotakis' foreign policy in the early 1990s went less far toward rapprochement with Turkey than Simitis'. While one can claim that the international climate and the experience of the Imia crisis was decisive in helping Simitis put through his new ideas, Mitsotakis also functioned under a favorable international environment as a liberal centre-right leader who came to power exactly when communism collapsed and the West was triumphant.

The reality was that for Mitsotakis polarization was a, devastating as it turned out, obstacle, while for Simitis it became an asset. Faced with intense opposition by a still populist PASOK against its economic and foreign policies (Eleftheriou and Tassis 2013, 142), ND under Mitsotakis invited the familiar accusations (mounted by the 'democratic camp' towards the Right) of subservience and weakness - especially since a different foreign policy issue, the Macedonia name-dispute, had arisen as a very salient and emotional topic in public debate. Even if they are two different issues, both Greek-Turkish relations and the Macedonia name-issue presented the two main parties with difficult decisions as they juggled new international conditions and significant internal divides between modernizers and nationalists. In 1993, ND fractured under the pressure of this divide. Just a few years later, PASOK's strategic position in polarized competition became the perfect vehicle for Simitis to put through his own ideas that actually were more advanced than anything Mitsotakis himself had attempted. With party competition 
revolving around the competition between a minoritarian Right and a majoritarian antiRight, the latent cleavage cutting through the entire party system could be negotiated more easily by the party benefiting from and fostering the language of polarization underpinning two-party competition. Hence paradoxically, rapprochement with Turkey finally came from politicians functioning from within the hitherto nationalistic and anti-Western 'democratic camp" 16 .

Party system dynamics, and especially polarization, also filtered the effect of new policy ideas on Greek foreign policy. The change in Helsinki represented potentially a farreaching rethinking of Greek foreign policy: away from a hostile view of Turkey and a maximalist reading of Greek interests to a view of Turkey as a partner and the acceptance of a pacified liberal order in the region under the auspices of the EU as a goal in its own, which in turn justified a reassessment of Greek interests in the Aegean (Tsakonas 2010). Given the Simitis government's adamant prioritization of Greek entry to the Eurozone, 'Europeanization' of Greek-Turkish relations was seen as a very important development not only in its own right, but also as part of the wider policy set of 'modernization'. Based on the ideas of Simitis and his circle of policymakers, and also given the general international and European context at the time, Greece could potentially enact in the culmination of these movements a foreign policy change high on Hermann's scale. This however was not the case: Both in terms of how the new policy was presented after Helsinki and in important actions of the Simitis government, Greek foreign policy retained a commitment to traditionally defined goals, even if these were reformulated to fit Greece's European aspirations. Party competition set the limits of how much change was possible (both practically and rhetorically).

Following the Helsinki Council, the Simitis government emphasized the recalibration of the relationship between the pursuit of Greek national interests and Greece's commitments arising from its EU membership ${ }^{17}$. Arguments along these lines stressed the political and economic benefits of a Europeanized Turkey and of Europeanization of Greek-Turkish relations (Kranidiotis 2000, 35; Tsakonas 2010, 96-97). Nevertheless, PASOK modernizers also argued about Helsinki with reference to traditional conceptions of Greek interests and dominant discourses in Greek foreign policy (Tsardanidis and Stavridis 2005). In the campaign for the April 2000 elections (that were called by Simitis prematurely to capitalize on the perceived success of Helsinki and the forthcoming entry into the Eurozone) PASOK emphasized the congruence of Helsinki with Greek foreign policy goals traditionally understood, forcing Turkey into concessions without alienating Greece from its European partners (Economides 2005, 484; Tsakonas 2010, 80-81). Even more critically, the government very vocally held to the mantra that Greece only accepted the demarcation of the continental shelf as a legitimate point of difference in the Aegean (Heraclides 2007, 202; Tsakonas 2010, 99-100). In addition, while normalization of relations with Turkey was supposed to assist the goal of fiscal consolidation, the Simitis government approved a massive armaments program. The improvement of Greece's 
deterrence capabilities was then used by Simitis to show that Greece still planned for all contingencies in the Aegean ${ }^{18}$.

The foreign policy practices and justifications of the government after Helsinki corresponded, almost point-by-point, to the needs of PASOK at the time. With a governing party in a party system of binary polarization as the host of their ideas, Simitis and modernizers were in a position to put through their policies as long as they were seen as congruent with PASOK's strategic needs. Presented as a tool used for the more effective promotion of traditional foreign policy goals, but also embedded in an ambitious and assertive language of innovative change, Helsinki served to bridge the divide between modernizers and nationalists inside the non-Right camp and maintain the credibility of PASOK as an anti-Right force. The insistence on the continental shelf mantra and the armaments program was particularly useful for PASOK to harness the support of its traditional following, satisfy key constituencies within the party, and counter pressure from parties on its left (Tsakonas 2010, 97). By the same token, the rhetoric of 'strong Greece' allowed PASOK to attack ND as a party unreliable for office (Lyrintzis 2005, 251; Vernardakis 2011, 21).

Thus, while Helsinki was presented as a 'European' policy, Simitis' rhetoric of 'strong Greece' contained nationalist undertones (Eleftheriou and Tassis 2013, 49) that crucially complemented efforts at mobilization of PASOK's audience ahead of an electoral contest that was shaping up to be very close. Ultimately, heading the call of anti-Right polarization as PASOK's main strategy, Simitis embedded Helsinki in a discourse that carried on the traditions of the 'democratic camp'. This entailed sticking to traditional definitions of Greek goals and interests, all the while the new policy was presented as an ingenuous way to satisfy Greece's European commitments. In managing to reconcile the new policy with PASOK's polarization strategy, the modernizers won the party over but had at the same time to significantly curtail its ambition and scope.

Helsinki of course did not go uncontested. The most vocal opponent was ND. ND was at the time in the middle of a process of renewal following the defeats of 1993 and 1996 and splits that led to the departure of politicians both of its nationalist and its liberal wing. Led by Costas Karamanlis since 1997, ND found itself in an awkward position after Simitis made modernization and Europeanization PASOK's goal. Karamanlis' goal was to reestablish ND's credibility as a governing party and as an agent of modernization without letting it slide back to the class-based neoliberal economics of the Mitsotakis years. Rather, his goal was to overcome the anti-Right polarization of PASOK by absorbing the discontent created by Simitis' policies within a pro-European and modernizing framework.

The opposition of ND to Helsinki accurately reflected the strategic constraints on the party at the time. While accepting the necessity of the European connection for Greece, Karamanlis objected to what seemed like a far-reaching reinterpretation of Greek foreign policy goals. His critique focused precisely on the ways the Helsinki agreement went against the established tenets of Greek foreign policy, namely the idea that there were 
issues for negotiation in the Aegean that called for political bargains. The critique of Karamanlis was further elaborated in the work of his key foreign policy advisers, who argued that Helsinki was inviting sacrifices for Greece and set insufficient checks on Turkey's aggression (Molyviatis 2002; Valinakis 2000). In this way, ND was reiterating the view that had become official Greek foreign policy since the 1980s, namely that Greece should refrain from negotiations with Turkey as much as possible, and was distancing somewhat from the legacy both of ND's founder Constantine Karamanlis in the 1970s and Mitsotakis in the 1990s who pursued dialogue with Turkey.

While agreeing with the goal of streamlining Greek foreign policy with European practices, Karamanlis opposed the agreement as not compatible with Greek interests traditionally understood. This was a difficult balance to maintain, but it was in agreement with government-opposition dynamics in a two-party system. Beyond just that though, the argumentations of ND in foreign policy closely mirrored the broader strategy of the party in the specific structure of polarization in the Greek party system. The goal of Karamanlis was to overcome anti-Right polarization by adopting a more popular profile and criticizing the externalities of Simitis' adjustment program even if accepting in principle the goal of entry into the Eurozone (Alexakis 2001, 118; Pappas and Dinas 2006, 491). This would allow ND to absorb the nationalism-modernization cleavage that was running through its own body and attract support from voters disgruntled with PASOK's turn (Lyrintzis 2005, 254).

Policy-empty two-party polarization then had repercussions for the way the foreign policy change was institutionalized beyond its immediate ratification. As expected by our analytical framework, the new foreign policy was partially institutionalized, especially since there was a government turnover merely four years after it had been instituted. Following its victory in the 2004 elections, ND undid essential aspects of the Helsinki bargain, suspending negotiations with Turkey over bilateral questions in the Aegean and preferring to keep pressure on Turkey through EU accession conditionality. In this way, the foreign policy change enacted in Helsinki ended up concerning mostly an atmospheric improvement of Greek-Turkish relations without forcing Greece into the potentially difficult decisions the original compromise entailed (e.g. negotiating territorial rights in the Aegean and recognizing some of Turkey's claims). While ND elites accepted the essential logic behind Helsinki (to adapt dimensions of Greek foreign policy to the demands of European membership), partisan expediency (both in the sense of avoiding political costs but also, more broadly, of overcoming anti-Right polarization and neutralizing the nationalism-modernization latent cleavage) influenced the way the party put this policy in practice. That Helsinki ended up being partially institutionalized corresponds to our expectations about how new foreign policies will fare after party turnover in government in a policy-empty polarized two-party system.

\section{CONCLUSIONS}


The aim of this article was to highlight the ways a focus on political parties can help fill the holes left in the analysis of foreign policy change by other approaches. In the case of Greece and the foreign policy change in Helsinki, prominent accounts focus on political leadership, entrepreneurship and culture, domestic institutions, and the role of Europe in socializing actors into new conceptions of interests. The roots of the change can be found in the activities of the modernizers around Simitis, functioning as policy entrepreneurs (like Blavoukos and Bourantonis theorized), promoting their own conceptions of a problemsolving policy (like Tsakonas analyzed) under the permissive condition of a changed international environment and the EU's course towards enlargement in the late 1990s. However all these arguments can be strengthened further if one incorporates the partisan needs of PASOK that had to be served if the foreign policy change was to go through. A focus on the dynamics of the Greek party system further complements our understanding of the timing, content and institutionalization of the foreign policy change at Helsinki. For example, as Blavoukos and Bourantonis mention political benefits to entrepreneurs after formulating the foreign policy change, these benefits can be primarily conceptualized as winning elections and staying in office. By the same token, Tsakonas' idea that leadership culture and general national culture interact in producing foreign policy change can be restated in terms of partisan actors engaging with the structures of the party system that embeds them.

In terms of analysis of Greek foreign policy, the narrative here focused on the key feature of the Greek party system, the binary polarization between PASOK and ND, and the strategies of the two parties as they tried to absorb a latent nationalism-modernization cleavage into existing structures of competition. I conclude that there was nothing inevitable about the specific change that Greece instituted, nor was the timing of the decision self-evident due to external stimuli, policy failures and so on. New policy ideas and political leadership mattered, as did changes in Greece's international environment and the impact of Europe, but the links between international and domestic factors pointing towards change are neither linear not clear-cut. The foreign policy change instituted in Helsinki needs to be problematized in terms of timing, degree and durability, and in this a focus on the context of the Greek party system is particularly rewarding. In short, policy ideas, leadership, political entrepreneurship or international pressures were conditioned by the opportunities and constraints contained in the structures of party competition.

More generally this article has tried to point to the role of party competition as an intervening variable of foreign policy. While it is not very original to claim that political actors go around party politics to promote their preferred policies (obviously they do), this article has preferred to look at political agency as embedded in a wider structure of competition that shapes in many respects the content of new policies and the durability of foreign policy change. The structure and type of polarization of party competition helps us formulate expectations about the ways policymakers are constrained to formulate 
responses to new international conditions, policy crises etc. It was seen that especially in policy-empty polarized two-party systems, new policy ideas have a better chance to find their way into official policies if they are formulated according to the dynamics of polarized competition, which also means that in the process they are being adapted and altered to a significant degree.

\footnotetext{
${ }^{1}$ By the mid-1990s the issues Turkey considered 'open' were: a) The demarcation of the continental shelf, b) demarcation of territorial waters, c) demarcation of the air space over the Aegean, d) militarization of Eastern Aegean islands, e) sovereignty over specific islands and islets, f) the limits of each country's operational air control over the Aegean Sea. For a thorough presentation of the legal parameters of these issues and an effort to present both sides of the argument, see Heraclides (2007, 217-382).

${ }^{2}$ See also the discussion in Economides (2005) and Moumoutzis (2011).

${ }^{3}$ This can be read inversely as well: The explanation one wants to prioritize to explain change informs how much of a change one thinks Helsinki is.

${ }^{4}$ On a theoretical discussion of the role of ideas in political change see, among others, Blyth (2003).

${ }^{5}$ Imia was the closest Greece and Turkey ever came to war. However previous crises were also perceived as very dangerous in Greece. The 1987 Aegean crisis had forced then Prime Minister Andreas Papandreou, who had instituted a policy of 'no dialogue', to enter into discussions with Turkey.

${ }^{6}$ This should be the norm in two-party systems. See Downs (1957) for the classical statement.

${ }^{7}$ This is in essence an expansion of the argument of Mavrogordatos (1984), while Kalyvas' (1997) analysis also agrees with it.

${ }^{8}$ PASOK went through a brief period of reassessment of its foreign policy in the late 1980s, following the 1987 crisis that almost led to armed engagement with Turkey. Andreas Papandreou accepted a dialogue process with Turkey on some of the bilateral issues (chiefly the continental shelf). But he quickly reverted to his old positions, also because his domestic position was becoming increasingly tenuous politically and electorally.

${ }^{9}$ Important works on foreign policy change are, among many, Gustavson (1999), Goldmann (1988), Holsti (1982) and Welch (2005).

${ }^{10}$ On foreign policy and political parties see, among others, Hofmann (2013), Kaarbo and Beasley (2008) and Rathbun (2004).

${ }^{11}$ Notice analogies with debates in international relations (especially constructivist) literature on the relationship between actors and the social structures they are embedded in (see Dessler [1989] for the classical epistemological statement).

${ }^{12}$ Here I follow Vernardakis' (2011) view of PASOK-ND competition in the 1980s and the early 1990s as reflecting tangible policy and social divides in Greece. Kalyvas (1997) challenges the view that PASOK and ND were genuinely separated by policy even in the 1980s.

${ }^{13} 50 \%$ of the population still was claiming in opinion polls in October 1999 to be against lifting the veto on Turkey (Tsakonas 2010, 216, note 309).

${ }^{14}$ See PASOK and ND's opinion poll standing throughout 1999-2000 in Simitis $(2005,645)$.

${ }^{15}$ On PASOK's long-standing anti-Right polarization strategy, see the very good discussion in Eleftheriou and Tassis $(2013,134-148)$.

${ }^{16}$ Further cementing this argument, during the second Simitis government (2000-2004) Greece also proceeded to completely Europeanize its approach to the Balkans and the Macedonia name-dispute, by leading the drive to accept the Western Balkan countries as EU candidates. Again, this was far from PASOK's populist positions up until the mid-1990s and its vehement opposition to Mitsotakis' efforts to reconcile Greece's Balkan policies and European membership.

${ }^{17}$ See Simitis' speech presenting PASOK's program ahead of the April 2000 elections, March 29, 2000, accessible in his personal webpage www.costas-simitis.gr. Also Economides (2005, 481-487).
} 
${ }^{18}$ Statements Simitis made at the presentation of the PASOK program for the April 2000 elections on March 29, 2000, and at PASOK's central electoral rally, April 7, 2000, accessible in his personal webpage www.costas-simitis.gr. 


\section{REFERENCE LIST}

Alexakis, Manolis. 2001. Centre-right ideology and New Democracy: The challenge and

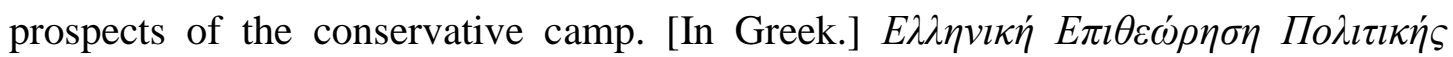

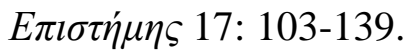

Athanassopoulou, Ekavi. 1997. Blessing in disguise? The Imia crisis and Turkish-Greek relations. Mediterranean Politics 2, no. 3: 76-101.

Bardi, Luciano and Peter Mair. 2008. The parameters of party systems. Party Politics 14, no. 2: 147-166.

Blavoukos, Spyros and Dimitris Bourantonis. 2012. Policy entrepreneurs and foreign policy change: The Greek-Turkish rapprochement in the 1990s. Government and Opposition 47, no. 4: 597-617.

Blyth, Mark. 2003. Ideas do not come with an instruction sheet: Interests, ideas, and progress in political science. Perspectives on Politics 4: 695-706.

Couloumbis, Theodore A. 2000. Greece in a post-Cold War environment. In Contemporary Greece and Europe, ed. Achilleas Mitsos and Elias Mossialos, 373-385. Aldershot: Ashgate.

Dessler, David. 1989. What's at stake in the agent-structure debate? International Organization 43, no. 3: 441-473.

Downs, Anthony. 1957. An economic theory of democracy. New York: Harper.

Economides, Spyros. 2005. The Europeanization of Greek foreign policy. West European Politics 28, no. 2: 471-491.

Eleftheriou, Costas and Chryssanthos Tassis. 2013. PASOK: The rise and fall (?) of a hegemonic party. [In Greek.] Athens: Savvalas.

Goldmann, Kjell. 1988. Change and stability in the international system: The problems and possibilities of détente. New York: Harvester Wheatsheaf.

Gustavsson, Jakob. 1999. How should we study foreign policy change. Cooperation and Conflict 34, no. 1: 73-95.

Heraclides, Alexis. 2007. Irreconcilable neighbors. Greece-Turkey: The Aegean conflict. [In Greek.] Athens: Sideris.

Hermann, Charles F. 1990. Changing course: When governments choose to redirect foreign policy. International Studies Quarterly 34, no. 1: 3-21.

Hofmann, Stephanie. 2013. European security in NATO's shadow: Party ideologies and institution building. Cambridge: Cambridge University Press.

Holsti, K.J. 1982. Why nations realign: Foreign policy restructuring in the postwar world. London and Boston: Allen and Unwin.

Huliaras, Asteris C. 1989. The foreign policy of the Greek socialists (1981-1986). Forces of continuity and change. $\mathrm{PhD}$ diss., University of Hull.

Ifantis, Kostas. 2004. Perception and rapprochement: Debating a Greek strategy towards Turkey. In Turkish-Greek relations. The security dilemma in the Aegean, ed. Mustafa Aydin and Kostas Ifantis, 245-268. London and New York: Routledge. 
Ioakimidis, Panayotis. 2000. The Europeanisation of Greece's foreign Ppolicy: Progress and problems. In Contemporary Greece and Europe, ed. Achilleas Mitsos and Elias Mossialos, 359-372. Aldershot: Ashgate.

Kaarbo, Juliette and Ryan K. Beasley. 2008. Taking it to the extreme: The effect of coalition cabinets on foreign policy. Foreign Policy Analysis 4: 67-81.

Kalyvas, Stathis N. 1997. Polarization in Greek politics: PASOK's first four years, 19811985. Journal of the Hellenic Diaspora 23, no. 1: 83-104.

Keridis, Dimitris. 2001. Domestic developments and foreign policy: Greek policy towards Turkey. In Greek-Turkish relations in the era of globalization, ed. Dimitris Keridis and Dimitrios Triantaphyllou, 2-18. Dulles, Va.: Brassey's.

Kranidiotis, Yannos. 2000. The fundamental objectives of Greek foreign policy. In Contemporary Greece and Europe, ed. Achilleas Mitsos and Elias Mossialos, 31-36. Aldershot: Ashgate.

Lijphart, Arend. 1999. Patterns of democracy. Government forms and performance in thirty-six countries. New Haven: Yale University Press.

Loulis, John C. 1984. Papandreou's foreign policy. Foreign Affairs 63, no. 2: 375-391.

Lyrintzis, Christos. 2005. The changing party system: stable democracy, contested 'modernisation'. West European Politics 28, no. 2: 242-259.

Mair, Peter. 1987. The changing Irish party system. Organisation, ideology and electoral competition. London: Frances Pinter.

Mair, Peter. 1997. Party system change: Approaches and interpretations. Oxford: Clarendon Press.

Mavrogordatos, George Th. 1984. The Greek party system: A case of 'limited but polarized pluralism'? West European Politics 7: 156-169.

Molyviatis, Petros G. 2002. The consequences of government policy on Greek-Turkish issues. [In Greek.] $\Phi_{l} \lambda \varepsilon \lambda \varepsilon v \dot{\theta} \theta \varepsilon \eta \eta ' E \mu \varphi \alpha \sigma \eta$ 10: 35-41.

Moschonas, Gerassimos. 1994. The Right/anti-Right cleavage in the post-dictatorship republic (1974-1990). Content of the cleavage and aspects of the strategy of the parties of the 'anti-right subsystem'. In Greek Political Culture Today, [In Greek.] ed. Nikos Demertzis, 159-215. Athens: Odysseas.

Moumoutzis, Kyriakos. 2011. Still fashionable yet useless? Addressing problems with research on the Europeanization of foreign policy. Journal of Common Market Studies 49, no. 3: 607-629.

Nicolacopoulos, Ilias. 2005. Elections and voters, 1974-2004: Old cleavages and new issues. West European Politics 28, no. 2: 260-278.

Pappas, Takis S. 2001. Party system and political competition in Greece, 1981-2001. [In

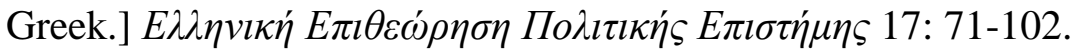

Pappas, Takis S. 2003. The transformation of the Greek party system since 1951. West European Politics 26, no. 2: 90-114. 
Pappas, Takis S. and Elias Dinas. 2006. From opposition to power: Greek conservatism reinvented. South European Society and Politics 11, no. 3-4: 477-495.

Pappas, Takis S. 2013. Why Greece failed. Journal of Democracy 24, no. 2: 31-45.

Rathbun, Brian C. 2004. Partisan interventions: European party politics and peace enforcement in the Balkans. Ithaca: Cornell University Press.

Rose, Richard. 1984. Do parties make a difference? London: Palgrave Macmillan.

Sartori, Giovanni. 1976. Parties and party systems: A framework for analysis. Cambridge: Cambridge University Press.

Simitis, Costas. 2005. Policy for a creative Greece, 1996-2004. [In Greek.] Athens: Polis.

Tsakonas, Panayotis J. 2010. The incomplete breakthrough in Greek-Turkish relations. Grasping Greece's socialization strategy. London: Palgrave Macmillan.

Tsardanidis, Charalampos. 1998. The foreign policy: 1990-1997. In PASOK: Party-StateSociety, [In Greek.] ed. Michalis Spourdalakis, 295-318. Athens: Patakis.

Tsardanidis, Charalampos and Stelios Stavridis. 2005. The Europeanisation of Greek foreign policy: A critical appraisal. Journal of European Integration 27, no. 2: 217239.

Tsoukalis, Loukas. 2000. Greece in the EU: Domestic reform coalitions, external constraints and high politics. In Contemporary Greece and Europe, ed. Achilleas Mitsos and Elias Mossialos, 37-51. Aldershot: Ashgate.

Valinakis, Yannis. 1989. Introduction to Greek foreign policy 1949-1988. [In Greek.] Thessaloniki: Paratiritis.

Valinakis, Yannis. 2000. The Helsinki decisions and EU-Turkey relations. In Review of Greek foreign and security policy. Greek-Turkish relations 1999-2000, [In Greek.] ed. Theodore Couloumbis and Thanos Dokos. Athens: ELIAMEP and Paratiritis.

Vernardakis, Christophoros. 2011. Political parties, elections and party system: The transformations of political representation 1990-2010. [In Greek.] Athens and Thessaloniki: Sakkoulas.

Welch, David A. 2005. Painful choices: A theory of foreign policy change. Princeton: Princeton University Press. 